\title{
Gene Expression of Promyelocytic Leukemia Proteins and IFN- $\gamma$ Is Reduced in Rotavirus-Infected Children
}

\author{
Ahmed Jasim Mohammed, Zeenah Weheed Atwan ${ }^{*}$, Aida Abdul-Kareem \\ Department of Biology, College of Science, University of Basra, Basra, Iraq
}

Received 23 February 2019; accepted 4 May 2019; published online 30 October 2019

\begin{abstract}
Background: Rotavirus infection is one of the most common gastroenteritis in the world, and a million cases are registered to enter hospital every year. PMLs are IFN-up-regulated proteins, and one of their critical functions is working as antiviral proteins. Recently, PML-II has been depicted as an isoform responsible for the antiviral function. Methods: Rotavirus prevalence determination was achieved by PCR and Rapid Adeno/Rota Virus test, while the relative expression assay was carried out by real-time PCR technique. Blood and stool samples were collected from 34 children under five years admitted to the hospital with acute gastroenteritis showing signs of dehydration. RNA samples were extracted from blood specimens and converted to cDNA to be used in gene expression analysis of PML, PML-II, and IFN- $\gamma$ in rotavirus positive or negative samples. Results: Rapid Adeno/Rota Virus Antigen Combo Test and PCR assay could detect the virus in stool samples in $45 \%$ and $17.6 \%$ of cases, respectively. PML in positive samples decreased to $10^{4}$ fold less than the level in negative ones. The same trend was noticed in the level of IFN- $\gamma$ and PML-II expression as their expression reduced to $10^{4}$ or 13 fold in rotavirusinfected samples compared to the control, respectively. Conclusion: Altogether, our data showed that the gene expression of PML, PML-II, and type II IFN considerably diminished in rotavirus-infected samples compared to the negative control. DOI: 10.29252/ibj.24.2.128
\end{abstract}

Keywords: Gene expression, IFN- $\gamma$, PML, PML-II, Rotavirus

Corresponding Author: Zeenah Weheed Atwan

Department of Biology, College of Science, University of Basra, Basra, Iraq; Mobile: (+964-77) 3566498; E-mail: z.w.atwan@warwick.ac.uk

\section{INTRODUCTION}

$\mathrm{R}$ Otavirus is an RNA virus discovered during a three-month survey in Melbourne and diagnosed as the causative agent of gastroenteritis by electron microscopy ${ }^{[1,2]}$. The virus genome is organized as ds RNA helicesz ${ }^{[3]}$. Using high or low multiplicity of infection, all 11 segments of the genomic dsRNA occur in the cytoplasm of the rotavirus-infected cells, indicating that they are replicating at an equal rate, and assembly is supported by ATP5B as an RNA-binding protein ${ }^{[4,5]}$. In fact, rotavirus infection stimulates the B-cell response as the first step to eliminate the virus infection. Monocytederived dendritic cells present the rotavirus antigens in non-human primates and increase the expression of IL6 , IL-8, and IFN- $\gamma^{[6,7]}$. Human rotavirus infection avoids the innate immune response by blocking the early IFN-I and IFN-II responses. Rotavirus stops the tumor necrosis factor-stimulated gene, namely NF-kB, which is critical for the stimulation of IFN response ${ }^{[8]}$.

PMLs were firstly discovered in acute promyelocytic leukemia patients as a part of oncogenic fusion protein called PML-RAR- $\alpha$. The PML gene has nine exons that undergo alternative splicing to form different PML isoforms with specific functions ${ }^{[9,10]}$. PML regulates the IFN response as a response to poly I:C stimulation, and PML-II inhibits the replication and the gene expression of adenovirus through the Hsp70 pathway ${ }^{[11,12]}$. 
During the viral infection, the IFN response is triggered through the sensing viral DNA or RNA, or other products by receptors in infected or neighbor cells $^{[13]}$. PMLs have been depicted as antiviral proteins due to the fact that they are IFN-up-regulated proteins and are the target of many RNA or DNA viruses ${ }^{[14-17]}$. Therefore, this study attempted to detect the virus prevalence and to analyze the effect of the infection on the innate immune response represented by PML and its regulatory effect on IFN- $\gamma$ or IFN-II.

\section{MATERIALS AND METHODS}

\section{Sample collection}

Thirty-four stool and blood samples were collected from children (under 5 years) with acute diarrhea in Basrah Hospital (Basrah, Iraq) from October to December 2017. Positive or negative samples were categorized depending on the presence of rotavirus RNA in stool samples.

\section{RNA extraction}

RNA was extracted from stool and blood samples to detect rotavirus RNA. Gene expression profiles of PML, PML-II, and IFN- $\gamma$ in rotavirus-infected children were compared with the negative samples. RNA was extracted using GENEzol ${ }^{\mathrm{TM}}$ TriRNA Pure Kit from Geneaid, Taiwan, following the manufacturer's instructions. Briefly, a suspension of stool samples (100 mg/900 $\mu \mathrm{l}$ of PBS) was spun down at $300 \times \mathrm{g}$ for $5 \mathrm{~min}$, and an equal volume of the supernatant and the lysis buffer were mixed, then the mix was transferred to the binding columns after adding ethanol at a ratio of $1: 1$. The columns were centrifuged at $16,000 \times \mathrm{g}$ for 1 minute, and the filtrate was discarded. The columns were then washed twice with $400 \mu \mathrm{l}$ or $600 \mu \mathrm{l}$ of washing buffer 1 or 2 , respectively, at $14,000 \times \mathrm{g}$ for 1 min each. Subsequently, columns were dried by centrifugation at $14,000 \times \mathrm{g}$ for $3 \mathrm{~min}$, and RNA was eluted with $30 \mu \mathrm{l}$ of RNase-free water, spinning down at $16,000 \times \mathrm{g}$ for $1 \mathrm{~min}$, and was kept at $-80{ }^{\circ} \mathrm{C}$. For RNA extraction from blood samples, $600 \mu \mathrm{l}$ of the lysis buffer were added to $200 \mu \mathrm{l}$ of the sample and mixed for a few seconds. Then the mixture was spun down for $1 \mathrm{~min}$ to eliminate the residues and the pure RNA was collected as described above.

\section{Reverse transcription reaction}

RNAs from both stool and blood samples were converted to cDNA using Accupower RocketScript RT Premix Kit (CA: K-2101, Bioneer, South Korea). The template RNA was mixed with the reaction components (oligo(dT), free DEPC water, and reverse transcriptase), and the final volume was adjusted to 20 $\mu 1$. The first cDNA strand was synthesized under conventional PCR conditions as follows: annealing at $25^{\circ} \mathrm{C}$ for $10 \mathrm{~min}$ and the reverse transcription reaction at $45{ }^{\circ} \mathrm{C}$ for $60 \mathrm{~min}$, which was heat inactivated at $95^{\circ} \mathrm{C}$ for $5 \mathrm{~min}$.

\section{Serological detection of the virus prevalence}

Rotavirus rapid test kit from Quick Profile Lumiquik (Cat 71033; Santa Clara, USA) was used to detect virus prevalence. Stool suspension (10\%) from each sample was added to the sample tray and was left to diffuse. Based on the kit instruction, the rotaviruspositive sample can be identified by development of two pink lines in positions $\mathrm{C}$ and $\mathrm{R}$ (" $\mathrm{C}$ " here means control, and " $\mathrm{R}$ " means rotavirus). The same kit could detect the adenovirus in each sample, but with two pink lines in positions $\mathrm{C}$ and A ("A" means adenovirus). However, the negative result is shown by a single pink line only in position $\mathrm{C}$, indicating that the sample does not contain adenovirus/rotavirus.

\section{PCR analysis}

AccuPower® PCR PreMix Kit (CA: K-2260-4; Bioneer) was used to achieve the amplification of rotavirus NSP3 fragment according to the instructions recommended by the manufacturer. All primers used in this study are listed in Table 1 . The reaction was prepared by mixing $5 \mu \mathrm{l}$ of template cDNA, one of each NSP3 forward and reverse primer, $2 \mu$ l of PCR Master Mix, and $11 \mu \mathrm{l}$ of free DEPC water to make a total volume of $20 \mu \mathrm{l}$. The PCR condition was set as : a denaturation step at $92{ }^{\circ} \mathrm{C}$ for $1 \mathrm{~min}$, followed by 30 cycles of $2 \mathrm{~s}$ of denaturation at $92{ }^{\circ} \mathrm{C}$, annealing at $52{ }^{\circ} \mathrm{C}$ for $15 \mathrm{~s}$, an extension step at $72{ }^{\circ} \mathrm{C}$ for $32 \mathrm{~s}$ with a final extension at $72{ }^{\circ} \mathrm{C}$ for $3 \mathrm{~min}$. PCR amplicons were electrophoresed and visualized on a $5 \%$ agarose gel.

\section{Real-time PCR}

Real-Time PCR reaction was prepared using AccuPower® GreenStarTM qPCR PreMix (CA: K6210 , Bioneer) according to the instructions provided by the manufacturer. The reaction mix with a total volume of $20 \mu \mathrm{l}$ was prepared by adding $5 \mu \mathrm{l}$ of template cDNA (concentration was adjusted to 5 $\mathrm{ng} / \mu \mathrm{l}), 1.5 \mu \mathrm{l}$ of each forward and reverse primer of PML, PML-II, and IFN- $\gamma$, and $12 \mu \mathrm{l}$ of free DEPC water. The real- time PCR condition was set as follows: a denaturation step at $94{ }^{\circ} \mathrm{C}$ for $3 \mathrm{~min}$, followed by 45 cycles of denaturation at $94{ }^{\circ} \mathrm{C}$ for $30 \mathrm{~s}$, annealing at $56{ }^{\circ} \mathrm{C}$ for $30 \mathrm{~s}$, and an extension step at 72 ${ }^{\circ} \mathrm{C}$ for $1 \mathrm{~min}$ with a final extension conducted at $72{ }^{\circ} \mathrm{C}$ for $5 \mathrm{~min}$. The reaction was subjected to the melting curve analysis to ensure the primer specificity. 
Table 1. Primers were used in this study to detect the virus prevalence and cellular gene expression

\begin{tabular}{ll}
\hline Primers & sequences \\
\hline NSP3 $^{[18]}$ & $\begin{array}{l}\text { Forward: ACCATCTACACATGACCCTC } \\
\text { Reverse: GGTCACATAACGCCCC }\end{array}$ \\
& $\begin{array}{l}\text { Forward: ACACCAGTGGTTCCTCAAGCA } \\
\text { PML }\end{array}$ \\
& Reverse: 5'-CTCGGCAGTAGATGCTGGTCA-3' \\
PML-II $^{[20]}$ & $\begin{array}{l}\text { Forward: AGGCAGAGGAACGCGTTGT } \\
\text { Reverse: GGCTCCATGCACGAGTTTC }\end{array}$ \\
& Forward: GTATTGCTTTGCGTTGGACA \\
${\text { IFN- }{ }^{[21]}}$ & Reverse: GAG TGT GGA GAC CAT CAA GGA \\
& \\
$\beta-$ actin $^{[22]}$ & Forward: CATCGAGCACGGCATCGTCA \\
& Reverse: TAGCACAGCCTGGATAGCAAC \\
\hline
\end{tabular}

\section{Ethical statement}

The above-mentioned sampling protocols were approved by the Research Ethics Committee of University of Basra, Basra, Iraq. Written informed consents were provided by the parents of the patients.

\section{RESULTS}

\section{Serology assay}

A serological test, using Quick Profile Lumiquik Kit (Santa Clara) was employed to detect rotavirus particles in 24 stool samples. The test relied on serological interaction with the viral particles in stool samples as an antigen. The results showed that $45 \%$ of samples were positive.

\section{PCR detection of rotavirus}

Molecular detection of rotavirus using a set of NSP3specific primers amplifying $100 \mathrm{bp}$ showed that only $17.6 \%$ of the samples were positive using the optimum PCR condition (Fig. 1).

\section{Specificity of primers and amplification curves}

Using Exicycler ${ }^{\mathrm{TM}} 96$ Software, the melting and amplification curves were detected and carefully compared to the non-template controls, and all the PCR amplicons were subjected to dissociation curve analysis to ensure the primer specificity. Each target gene PML, PML-II, IFN- $\gamma$ and $\beta$-actin the control gene showed single peak (Fig. 2). Measurable fluorescence signal from SYBR green emission was detected from PML, PML-II, IFN- $\gamma$, and $\beta$-actin reaction tubes. Although they appeared at late cycles, it was sufficient to be distinguished from the non-template control (Fig. 3). PML amplification curve was detected using PML qPCR specific primers (Fig. 3A). In order to detect which isoform of PML proteins is responsible for counteracting antiviral response against rotavirus infection, PML-II expression was measured using specific primers, the amplification curve was investigated and the threshold was set automatically (Fig. 3B). PML-related genes have been wellconnected to PML functions in literatures, and it has been mentioned that there is a cross-talk between ISG and $\mathrm{PML}^{[11]}$. Therefore, the amplification curve of IFN- $\gamma$ - was detected using specific primers (Fig. 3C), While all the relative expression was assessed by subtracting $\beta$-actin CT value which again showed an amplification curve using $\beta$-actin specific primers (Fig. $3 \mathrm{D})$. in all cases, the gene expression profile was calculated based on on $\Delta \Delta \mathrm{CT}$ analysis.

\section{PML relative expression in rotavirus-infected samples}

To evaluate the PML gene expression as a response to rotavirus infection, RNAs extracted from blood samples were used as templates for cDNA preparations. cDNA template was then used in qPCR relative expression assay (SYBR green). Apparently,
(A)

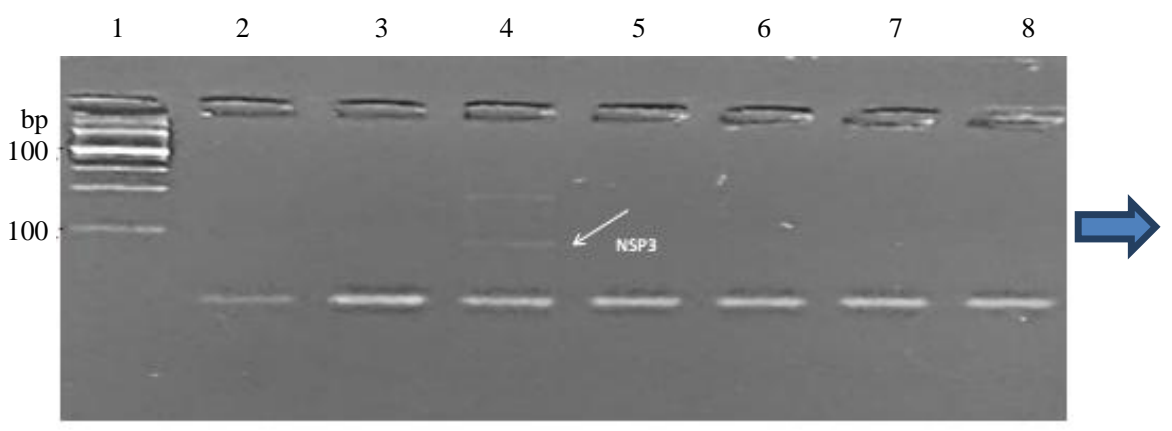

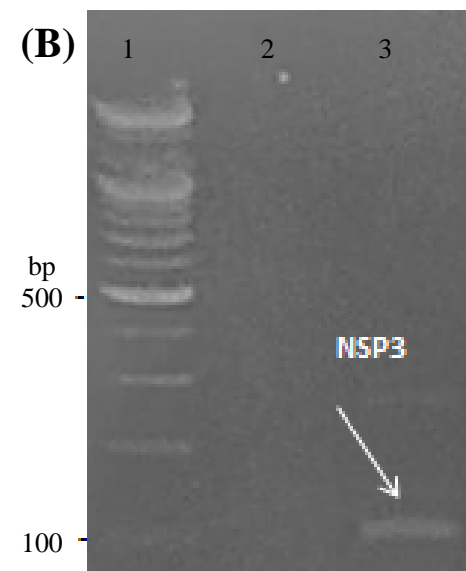

Fig. 1. Agarose gel electrophoresis of PCR-amplified products of rotavirus species-specific primers (NSP3) using: (A) $2 \%$ agarose: lane 1, 100 bp DNA size marker; lane 2, no template (negative) control; lanes 3-8 the examined sample. (B): 5\% agarose: lane 1, 100 bp DNA size marker; lane 2, no template control; lane 3, an examined sample. 

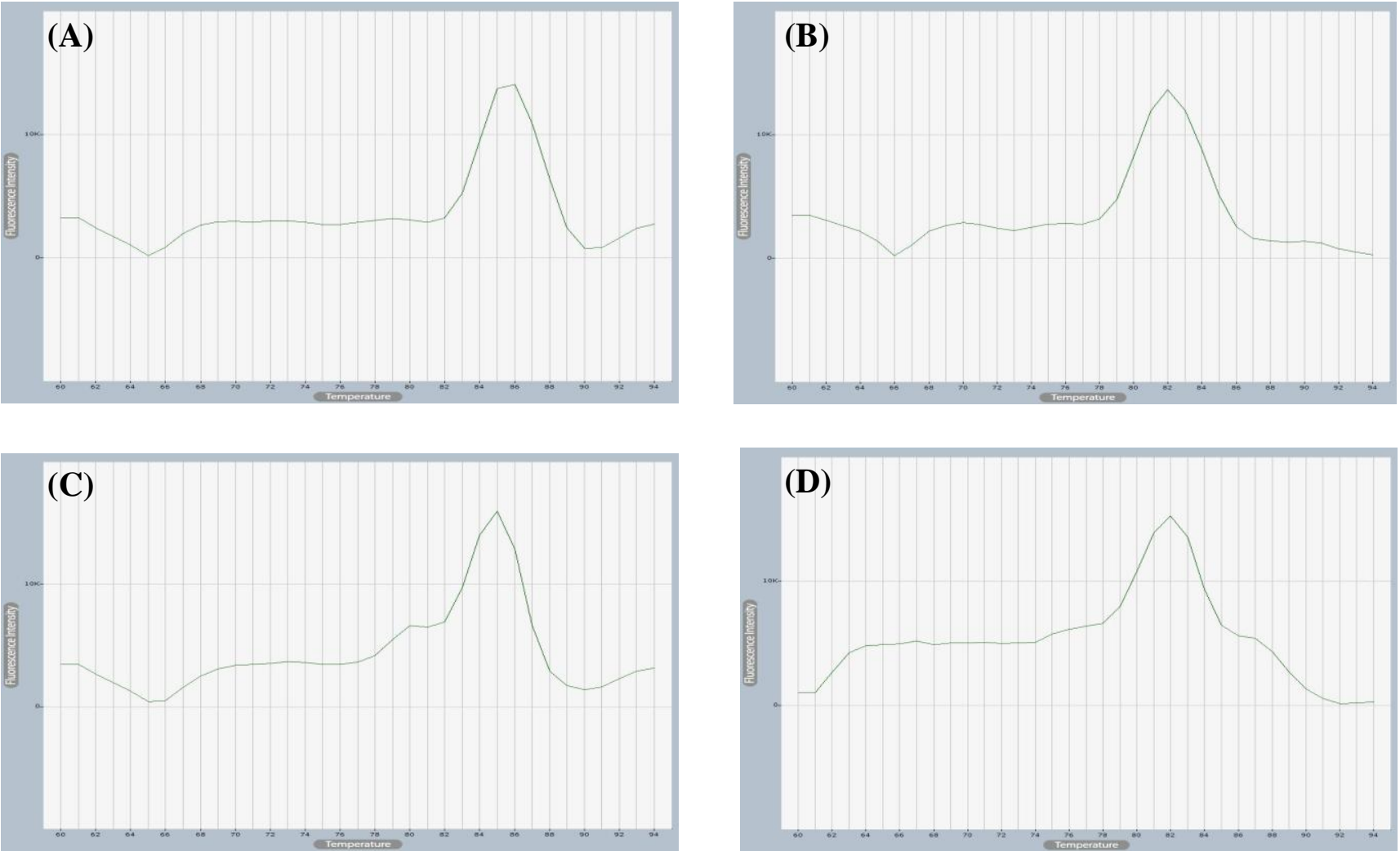

Fig. 2. Melting curve analyses of PML, PML-II, IFN- $\gamma$, and $\beta$-actin. Fluorescence change was measured with increasing temperature to separate the ds of the DNA to form single-stranded DNA. Fluorescence stops when SYBR green dissociates from the DNA. One dissociation curve was obtained for PML (A), PML-II (B), IFN- $\gamma$ (C), and $\beta$-actin (D) genes amplified by the qPCR SYBR green, which showed one peak at $82{ }^{\circ} \mathrm{C}, 78^{\circ} \mathrm{C}, 82^{\circ} \mathrm{C}$, and $82{ }^{\circ} \mathrm{C}$, respectively.

the expression level of PML was found to be significantly higher in negative samples detected by either molecular analysis or serological test or by both approaches when compared to the positive samples. The fluorescence signal of PML lagged more or less five cycles behind the negative sample signal.

The value of $\beta$-actin amplification was subtracted from PML value of each sample. The $\Delta \Delta \mathrm{CT}$ analysis was used here by subtracting the resultant value of the control samples from that of the infected sample. The data were then analyzed by normalizing the negative control samples to 1 . Then the number of folds difference in the PML expression was calculated. Expression of PML in positive samples was roughly less than 10,000fold compared to its value in the negative control samples (Fig. 4A).

\section{PML-II gene expression}

Given the important role of PML-II in regulating the IFN response and its negative role in adenovirus lifecycle, the expression pattern of PML-II was examined. Again, cDNAs from the total blood RNA were made and used as templates for relative gene expression assay normalized to the control genes. In consistent with the total PML expression profile, PMLII expression was drastically reduced in rotavirusinfected samples compared to the control ones that their amplification appeared two CTs earlier. To conclude the fold change value, the negative control sample was normalized to 1 to which the positive value was compared. In fact, the PML-II expression showed a 10,000 fold reduction compared to the control (Fig. 4B).

\section{IFN- $\gamma$ expression profile}

Due to the well-known correlation between TRIM-19 family (which PML belongs to) and IFN and antiviral immune response, IFN- $\gamma$ gene expression profile in both rotavirus-positive or negative samples were examined for IFN- $\gamma$ mRNA expression. In consistent with the expression profile of PML, in rotavirusinfected samples, IFN- $\gamma$ expression wasmassively lower than its level in the negative samples. Again, the CTs of IFN- $\gamma$ in positive samples appeared six CTs behind the negative ones, and the real values of the expression were obtained by $\Delta \Delta \mathrm{CT}$ analysis.

Moreover, to exactly detect the fold change, the values of IFN- $\gamma$ in negative samples were normalized 

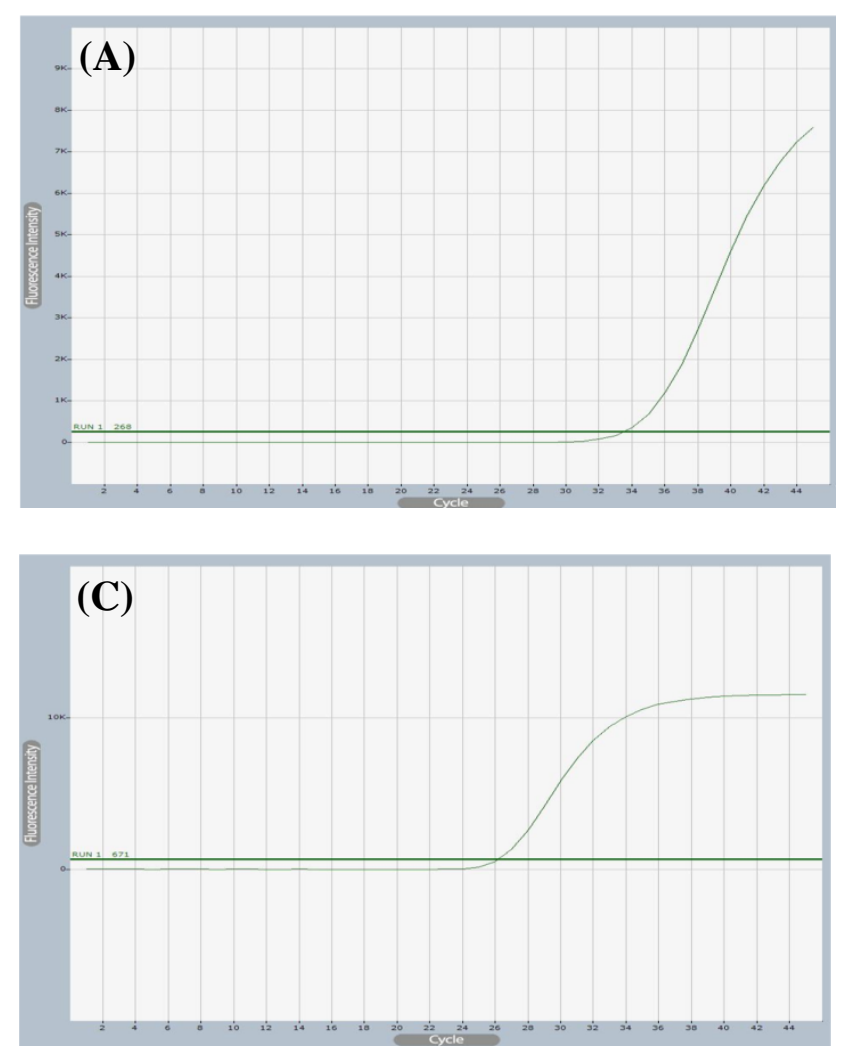
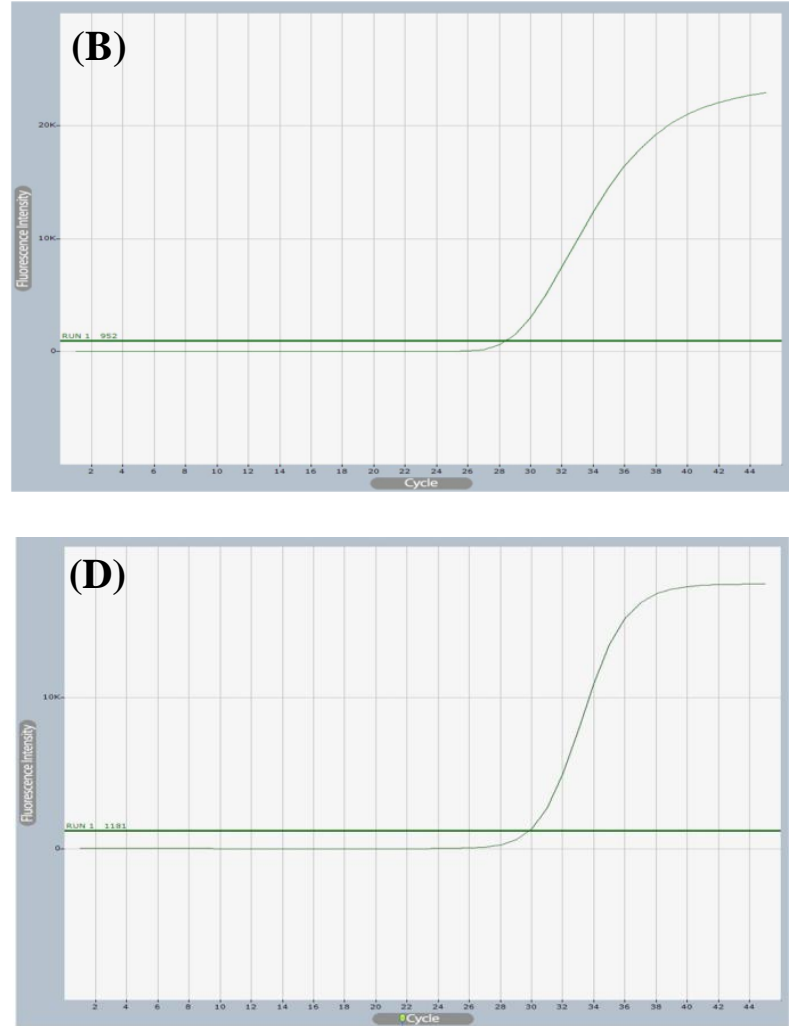

Fig. 3. Representative amplification curves of PML, PML-II, IFN, and $\beta$-actin. Amplification curves were generated by plotting the cycle number at the crossing point with the threshold value versus the log of starting amount of template. Clear amplification curves were obtained for PML (A), PML-II (B), IFN (C), and $\beta$-actin (D), respectively.

to 1 , which showed that IFN- $\gamma$ expression increased to about 40,000fold in the negative samples (Fig. 4C).

\section{DISCUSSION}

Rotavirus infects children, particularly under five years of age ${ }^{[23]}$. Most of the diarrhea samples in this study were from children aged from 2-27 months, similar to studies from other Asian countries, such as Pakistan ${ }^{[24,25]}$. Our sample collection was conducted during autumn since rotavirus infection often increases with cold seasons and reduces during spring or summer; this is in agreement with a previous study conducted in Australia where infection with rotavirus declines in Summer ${ }^{[26]}$.

The molecular detection (PCR) of rotavirus prevalence in our study showed to be $17.6 \%$, while the serological test indicated a prevalence of $45 \%$. Rotavirus detection by PCR was less than what was reported in Kiambu, Kenya, which reached $68.2 \%{ }^{[27]}$. Such difference might belong to the target gene amplified in the PCR as the genes in Kenya study were VP4 and VP7, while, in this study, NSP3 was the specific amplicon. The other reason for this discrepancy might be due to the larger number of population studied since the number of samples surveyed in Kenya was 85 with 58 positive samples, but the total number of samples in the present study was 34 with only six positive cases. However, in future, using a larger size of samples is strongly recommended that might give better insights into the incidence of infection and how frequent is each type of rotavirus in affected children. The serological test in our investigation showed a higher prevalence percentage compared to other studies, which could be due to the differences in the serological methods employed in each study; ELISA was used as a detection tool in other studies ${ }^{[27]}$. Another reason is the cross-reactivity that might be generated due to the presence of anti-adenovirus antibodies in the same pad that also contains anti-rotavirus antibodies in Quick Profile Limiquik serological reaction.

Once IFN- $\gamma$ is stimulated in the virus-infected cells, it attaches to a specific receptor in the surface of the neighboring (uninfected) cell. Consequently, STAT1 is phosphorylated and both types (STAT1-STAT2) bind to translocate from cytoplasm to nucleus and are recruited into the IFN- $\gamma$ promoter activation site to induce several ISGs ${ }^{[28]}$. 
(A)

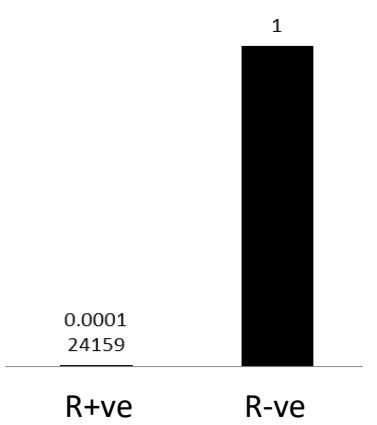

(B)

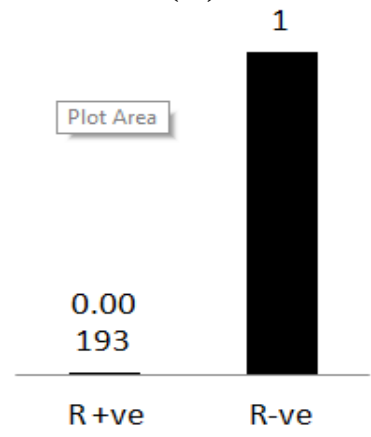

(C)

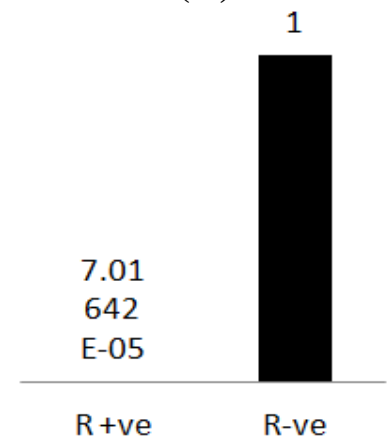

Fig. 4. RT and real-time PCR analysis of PML (A), PML-II (B), and IFN- $\gamma$ (C) mRNA relative expression in positive and negative samples. Transcript levels were quantified in cDNAs obtained from positive or negative samples using the expression of $\beta$-actin as an internal control. Relative expression assay was achieved using SYBR green as intercalating dye. Obtained data were analyzed by $\Delta \Delta \mathrm{CT}$ s and then normalized to the control samples, which were equalized to 1 .

Our results showed that IFN- $\gamma$ decreases in the positive samples of rotavirus in contrast to the negative samples, which is mainly due to the developed mechanisms established by many viruses to confront the innate immunity, in order to replicate efficiently inside the cell without any restriction by the body defenses, such as IFNs. In line with our finding, Hakim et al. ${ }^{[29]}$, who conducted his study in murine models using IFN-I $(\alpha, \beta)$ and IFN-II $(\gamma)$ as a therapy against rotavirus, failed in defense and giving resistance against the invaded rotavirus. These results proved that IFN-I and -II have a secondary role in controlling rotavirus infection in mice and also suggested that IFN-III (IFN- $\lambda$ ) is advantageous in mice models and is inhibited by the virus in intestinal epithelial cells ${ }^{[29-31]}$, which gives a better resistance against rotavirus. It has also been revealed that the gene expression of IFNs is down-regulated by rotavirus infection ${ }^{[32]}$; a rotavirus developed mechanism impedes STAT-Y701 phosphorylation with IFN overexpression ${ }^{[33]}$. In HT29 cells, STAT-Y701 is phosphorylated as a response to exogenous IFNs such as IFNs I, II, and III; furthermore, infected HT29 cell with simian RRV RV strain or Porcine SB1-A showed a decline in the level of IFN- $\gamma 1$ receptor gene expression occurring 6-8 h post infection with these two viruses.

The IFN stimulation step is restricted by viral proteins. These viral proteins have influence on the activation of certain transcription factors in the cytoplasm of the infected cells. Rotavirus has a protein, called nonstructural protein NSP1, that is able to inhibit the IFN production. This protein can restrict IFN- $\alpha, \beta$ production by proteasome-dependent degradation through proteasome transcription factors such as IRF3, IRF7, and IRF5. NSP1 can also restrict activation of NFkB. IRF3, IRF7, and IRF5, and NF-kB are the main factors that promote the IFN production ${ }^{[34]}$. Similarly, it has been demonstrated that IFN is produced when ${ }^{[35]}$ NSPI of rotavirus destroys the IRF3. In addition to the restriction effect of rotaviruses on IFN production ${ }^{[34]}$, these viruses can inhibit STAT1 and STAT2 expression $^{[5]}$.

In our case, the samples were collected after the symptoms of diarrhea and dehydration started, normally at two days post infection. Progeny virus is formed after 10 to 12 hours, which is then released to infect other cells and to shed inside the lumen of the intestine ${ }^{[36]}$. Hence, the reduced expression of IFN and PML might be due to the time when the samples were collected as the virus had enough time to enter, establishing its own replication centers and synthesizing the structural proteins. This gap in time between triggering the IFN response and the appearance of symptoms is when the virus controls the cellular machinery and blocks the IFN response. In fact, the IFN response is triggered at two hours post infection, reaching the maximum at six hours post infection $^{[37]}$; therefore, time is a critical factor here. PML expression has an inhibitory effect on the virus lifecycles, making it sensitive to IFN response and restricting its growth. For example, in case of influenza A the viral replication is reduced with the overexpression of PML and recovered with the removal of PML ${ }^{[38]}$. PML expression, especially I-IV, increases when IFN- $\gamma$ induces STAT1phosphorylation to induce the ISG. PML knockdown will reduce the phosphorylation of STAT1 induced by IFN- $\gamma$; as a consequence, it decreases the levels of ISG transcription $^{[39]}$.

Our results displayed that PML-II gene expression decreased in positive samples, and this might be due to the reduction in the level of gene expression of IFN- $\gamma$ and total PML. As was mentioned by ${ }^{[28]}$, IFN- $\gamma$ production in a cell infected by virus will stimulate the 
neighboring cell during JAK-STAT signaling and hundreds of ISGs are activated. Up-regulated PML gene expression by IFN-I or -II increases the expression of PML-II, while decrease in the PML level will certainly decrease the PML-II expression. There are many cytokines that stimulate IFN- $\gamma$-II; for example, IL-12, IL-2, IL-18, IL-15, and IFN-I $(\alpha, \beta)$. All these cytokines are critical to the stimulation of IFN- $\gamma$ in natural killer cells. Therefore, IFN-I $(\alpha, \beta)$ has a significant role in stimulating IFN- $\gamma$, and inhibiting the expression of PML-II results in down-regulationn of IFN- $\beta$ and ${ }^{[40-42]}$ Hence, the increased level of gene expression of IFN- $\beta$ was noticed when PML-II expression was augmented. Similarly, when PML-II levels are reduced, IFN promoter activity is reduced to $25 \%$ compared to the control ${ }^{[8]}$. In conclusion, it could be a chain of events because IFN- $\beta$ reduction lowers PML-II expression and as a consequence expression of IFN- $\gamma$ (which is IFN I- regulated gene) is reduced. Accordingly, in the positive samples the production of IFN- $\gamma$ would be affected by IFN-1, such as IFN- $\beta$, and reduction in gene expression of IFN- $\gamma$ in turn decreased the gene expression of PML-II.

\section{CONFLICT OF INTEREST. None declared.}

\section{REFERENCES}

1. Bishop RF, Davidson GP, Holmes IH, Ruck, BJ. Virus particles in epithelial cells or duodenal mucosa from children with acute, non-bacterial gastroenteritis. Lancet 1973; 2(7841): 1281-1283.

2. Flewett TH, Bryden H, Davies H, Woode GN, Bridger JC, Derrick JM. Relationship between viruses and acute gastroenteritis of children and newborn calves. Lancet 1974; 2(7872): 61-63.

3. Prasad BV, Rothnage R, Zeng CQ, Jakana J, Lawton JA, Chiu W, Estes MK. Visualization of ordered genomic RNA and localization of transcriptional complexes in rotavirus. Nature 1996; 382(6590): 471473.

4. Patton JT. Evidence for equimolar synthesis of doublestrand RNA and minus-strand RNA in rotavirus-infected cells. Virus research 1990; 17(3): 199-208.

5. Ren L, Ding S, Song Y, Li B, Ramanathan M, Co J, Amieva MR, Jhavari, PA, Greenberg HB. Profiling of rotavirus 3'UTR-binding proteins reveals the ATP synthase subunit ATP5B as a host factor that supports late-stage virus replication. Journal of biological chemistry 2019; Retrieved from: http://www.jbc.org/ content/early/2019/02/15/jbc.RA118.006004.

6. Blutt SE, Warfield KL, Lewis DE, Conner ME. Conner. Early response to rotavirus infection involves massive B cell activation. Journal of immunology 2002; 168(11): 5716-5721.

7. Sestak K, McNeal MM, Choi A, Cole MJ, Ramesh J,
Alvarez X, Aye PP, Bohm RP, Mohamadzadeh M, Ward RL. Defining T-cell-mediated immune responses in rotavirus-infected juvenile rhesus macaques. Journal of virology 2004; 78(19):10258-10264.

8. Holloway G, Truong TT, Coulson BS. Rotavirus antagonizes cellular antiviral responses by inhibiting the nuclear accumulation of STAT1, STAT2, and NFkappaB. Journal of virology 2009; 83(10): 4942-4951.

9. De Thé H, Lavau C, Marchino A, Chmoienne C, Degos, L, Dejean A. The PML-RAR alpha fusion mRNA generated by the $t(15 ; 17)$ translocation in acute promyelocytic leukemia encodes a functionally altered RAR. Cell 1991; 66(4): 675-684.

10. Fagioli M, Alcalay M, Pandolfi PP, Venturini L, Mencarelli A, Simeone A, Acampora D, Grignani F, Pelicci, PG. Alternative splicing of PML transcripts predicts coexpression of several carboxy-terminally different protein isoforms. Oncogene 1992; 7(6): 10831091.

11. Chen Y, Wright J, Meng X, Leppard KN. Promyelocytic leukemia protein isoform II promotes transcription factor recruitment to activate interferon beta and interferon-responsive gene expression. Molecular and cellular biology 2015; 35(10): 1660-1672.

12. Atwan Z, Wright J, Woodman A, Leppard K. Promyelocytic leukemia protein isoform II inhibits infection by human adenovirus type 5 through effects on HSP70 and the interferon response. Journal of general virology 2016; 97(8): 1955-1967.

13. Koyama S, Ishii KJ, Coban C, Akira S. Innate immune response to viral infection. Cytokine 2008; 43(3): 336341 .

14. Wilkinson GW, Kelly C, Sinclair JH, Ricards C. Disruption of PML-associated nuclear bodies mediated by the human cytomegalovirus major immediate early gene product. Journal of general virology 1978; 79(Pt 5): 1233-1245.

15. Ullman AJ, Hearing P. Cellular proteins PML and Daxx mediate an innate antiviral defense antagonized by the adenovirus E4 ORF3 protein. Journal of virology 2008; 82(15): 7325-7335.

16. Everett RD, Chelbi-Alix MK. PML and PML nuclear bodies: Implications in antiviral defence. Biochimie 2007; 89(6-7): 819-830.

17. Marini B, Giacca M, Lusic M. 126 PML nuclear bodies determine the repressive environment and restrict viral gene expression in primary human lymphocytes. Journal of acquired immune deficiency syndrome 2011; 56: 51.

18. Gachanja E, Buza J, Petrucka P. Molecular detection of group A rotavirus in children under five in urban and peri-urban Arusha, Tanzania. British journal of medicine and medical research 2016; 12: 1-9.

19. Dutrieux J, Maariff G, Portilho DM, Arhel NJ, ChelbiAlix MK, Nisole S. PML/TRIM19-dependent inhibition of retroviral reverse-transcription by Daxx. PLoS pathogens 2015; 11(11): e1005280

20. Atwan Z, Wright J, Woodman A, Leppard, KN. Promyelocytic leukemia protein isoform II inhibits infection by human adenovirus type 5 through effects on 
HSP70 and the interferon response. The journal of general virology 2016; 97(8): 1955-1967.

21. Padua D, Mahurkar-Joshi S, Law IK, Polytarchou C, Vu JP, Pisegna JR, Shih D, Liopoulos D, Pothoulakis C. A long noncoding RNA signature 75 for ulcerative colitis identifies IFNG-AS1 as an enhancer of inflammation. American journal of physiology-heart and circulatory physiology 2016; 311(3): 446-457.

22. Zhu B, Wang JY, Zhou JJ, Zhou F, Cheng W, Liu YT, Wang J, Chen X, Chen DH, Luo L, Hua ZC. PMLRAR $\alpha$ stabilized by zinc in human acute promyelocytic leukemia NB4 cells. Journal of inorganic biochemistry 2017; 175: 92-100.

23. D'souza RM, Hall G, Becker NG. Climatic factors associated with hospitalizations for rotavirus diarrhoea in children under 5 years of age. Epidemiology and infection 2008; 136(1): 56-64.

24. Habib MI, Kazi SG, Ahmad Khan KM, Zia N. Rota virus diarrhea in hospitalized children. Journal of the college of physicians and surgeons Pakistan 24(2): 114117.

25. Vesikari T. Rotavirus vaccination: a concise review. Clinical microbiology and infection 2012; 18(Suppl 5): 57-63.

26. Campbell SJ, Nissen MD, Lambert SB. Rotavirus epidemiology in Queensland during the pre-vaccine era. Conditions and diseases 2009; 33(2): 204-208.

27. Apondi WE. Detection and molecular characterization of rotavirus strains isolated from children attending selected health facilities in Kiambu district, Kenya. Reterieved from: https://pdfs.semanticscholar.org/bada/ 1f520e95041b539336e99122604df88438b0.pdf.

28. Schneider WM, Chevillotte MD, Rice CM. Interferonstimulated genes: a complex web of host defenses. Annual review of immunology 2014; 32: 513-545.

29. Hakim MS, Chen S, Ding S, Yin Y, Ikram A, Ma XX, Wang W, Peppelenbosch MP, Pan Q. Basal interferon signaling and therapeutic use of interferons in controlling rotavirus infection in human intestinal cells and organoids. Scientific reports 2018; 8341 (2018).

30. Pott J, Mahlakõiv T, Mordstein M, Duerr CU, Michiels $\mathrm{T}$, Stockinger $\mathrm{S}$, Hornef MW. IFN- $\lambda$ determines the intestinal epithelial antiviral host defense. Proceedings of the national academy of sciences 2011; 108(19): 7944-7949.

31. Hernández PP, Mahlakoiv T, Yang I, Schwierzeck V, Nguyen N, Guendel F, Gronke K, Ryffel B, Holscher C, Dumoutier L, Renauld JC, Suerbaum S, Staeheli P,
Diefenbach A. Interferon- $\lambda$ and interleukin 22 act synergistically for the induction of interferon-stimulated genes and control of rotavirus infection. Nature immunology 2015; 16(7): 698-707.

32. Sen A, Sharma A, Greenberg HB. Rotavirus degrades multiple interferon (IFN) type receptors to inhibit IFN signaling and protects against mortality from endotoxin in suckling mice. Journal of virology 2017; 92(1): pii: e01394-17.

33. Sen A, Rott L, Phan N, Mukherjee G, Greenberg HB. Rotavirus NSP1 protein inhibits interferon-mediated STAT1 activation. Journal of virology 2014; 88(1): 4153.

34. Graff JW, Ettayebi K, Hardy ME. Rotavirus NSP1 inhibits NFאB activation by inducing proteasomedependent degradation of $\beta$-TrCP: a novel mechanism of IFN antagonism. PLoS pathogens 2009; 5(1): e1000280.

35. Arnold MM, Barro M, Patton JT. Rotavirus NSP1 mediates degradation of interferon regulatory factors through targeting of the dimerization domain. Journal of virology 2013; 87(17): 9813-9821.

36. Parashar UD, Nelson EA, Kang G. Diagnosis, management, and prevention of rotavirus gastroenteritis in children. The BMJ 2013; 347: f7204.

37. Deal EM, Jaimes MC, Crawford SE, Estes MK, Greenberg HB. Rotavirus structural proteins and dsRNA are required for the human primary plasmacytoid dendritic cell IFN $\alpha$ response. PLoS pathogens 2010; 6(6): e1000931

38. Iki S, Yokota SI, Okabayashi T, Yokosawa N, Nagata K, Fujii N. Serum-dependent expression of promyelocytic leukemia protein suppresses propagation of influenza virus. Virology 2005; 343(1): 106-115.

39. El Bougrini J, Dianoux L, Chelbi-Alix MK. PML positively regulates interferon gamma signaling. Biochimie 2011; 93(3): 389-398.

40. Li MO, Sanjabi S, Flavell RA. Transforming growth factor- $\beta$ controls development, homeostasis, and tolerance of $\mathrm{T}$ cells by regulatory $\mathrm{T}$ cell-dependent andindependent mechanisms. Immunity 2006; 25(3): 455471.

41. Li MO, Wan YY, Sanjabi S, Robertson AKL, Flavell RA. Transforming growth factor- $\beta$ regulation of immune responses. Annual review of immunology 2006; 24: 99-146.

42. Schoenborn JR, Wilson CB. Regulation of interferon- $\gamma$ during innate and adaptive immune responses. Advances in immunology 2007; 96: 41-101. 